\title{
WASTEWATER COLLECTION PERFORMANCE ON COMMUNAL SANITATION SYSTEM IN CIMAHI INDONESIA
}

\author{
Mohamad Rangga Sururi, Siti Ainun, dan Fikri Abdillah \\ Environmental Engineering Department, Institut Teknologi Nasional, PKH.Mustopha no.23, Bandung, West Java, \\ Indonesia \\ rangsoer@yahoo.com,sitiainun@yahoo.com,abahimovic@yahoo.com
}

\begin{abstract}
In dense population cities, the effectiveness of the communal system in handling municipal domestic wastewater is important. This research aimed to evaluate the effectiveness of pipe dimensioning process and determine it as a wastewater collector to be served as a reactor through a tracer test. Thus, this work may give some inputs for a reliable design criteria for communal system in Indonesia. The reaserch area was at communal system on Tegal Kawung RT 05 RW 08. It served 37 household which was identified using built drawings and field checking. The number of communal septic tank user was 150 people who approximately use water of 134.33 L/person/day and more than $75 \%(107.46$ L/persons/day )was discharged to the system. The tracer test was done between the control box with the distance of 27.94 $m$ and diameter of $150 \mathrm{~mm}$. Based on the mathematical model that was used, the diameter of the pipe should be $100 \mathrm{~mm}$. The tracer test showed that the piping system is the Plug Flow Reactor but it is not yet effective, shown by the MDI value of 3.36 .
\end{abstract}

Keywords: Communal System, Sewerage System, Design Criteria, Tracer Test.

\section{INTRODUCTION}

In most big cities in Indonesia, the municipal domestic wastewater has always been becoming a major cause for the degradation of environmental quality. Inappropriate handlings causes the increase of the number of waterborne disease cases increase and turn into one of major diseases especially for those who lived in high dense and slum dwelling area. Furthermore, with insufficient sanitation is one of the biggest contributing issues to child mortality under the age of five and yet it remains the most neglected of the Millennium Development Goal (MDG) sectors (Cumming, 2009).

According to the Ministry of Public Work, the area with density of $100-150$ persons/Ha must be equipped by an offsite sanitation system. However, the offsite system investment and the operational budget are very expensive so that many cities in Indonesia could not afford to build and operate the system. This problem is faced by so many cities in Indonesia, it can be seen from the small number of cities in which the offsite systems are built.

This research was done in Cimahi City, West Java Province, Indonesia, which consists of three districts. Its location is near Bandung, the capital of West Java province. The population of Cimahi City in 2008 is 579,802 people, making this city have a density of 144 persons/Ha. Its population growth rate is $2.58 \%$ within $2003-2007$ which makes the growth trend is exponential with a positive 
rate in the average of 13,345 persons per year (Badan perencanaan dan pembangunan Kota Cimahi, 2013).

It is essential for Cimahi City to have an offsite system of sanitation due to its high density. Furthermore, according to the Storet Index, the rivers in Cimahi were highly polluted (Kantor Lingkungan Hidup Kota Cimahi, 2010) . However, high investment of the system becomes a constrain to fulfill the needs. As an urge response, Cimahi government has built communal systems at several dense areas. One of them is located at RT 05 RW 08 Tegal Kawung Village, Cipageran Sub District, North Cimahi District, built in 2013 and serves 37 house connections.

The appropriate technology must be applied for a communal system. This means that the technologies must be both low cost and affordable (Mara, 2003). Establishment of individual sanitation facilities in dense area seems unfeasible due to the high population density and the high poverty levels. Nevertheless, a sustainable sanitation system must be technically feasible, adequate to the users, affordable and contribute to health improvement and environmental protection (Katukiza, et al., 2012).

The settlement of domestic waste pollution problems for Cimahi and the other big cities in Indonesia will be relied on the reliability of communal system, therefore the effectiveness of the wastewater collection system performances must be known. One of the important parts of communal system is the sewerage system. The sewerage system is commonly the PVC pipe which collects the wastewater from every house to the septic tank.

The research about wastewater collection system has been started since the odor from the system was detected (Hvitved-Jacobsen, et al., 2001). Huisman (2001) found that there are important processes at the sewerage system which cause the change of wastewater composition from the source to the treatment plant. This information shows that the wastewater collection system is not only functioning as a transporter but also a reactor so that the concentration of non-conservative pollutant will be degraded.

Although appropriate technology not only refers to the tools and techniques (Murphy, et al., 2009), a reliable collection and treatment of wastewater are among the important factors which can improve the global health and sanitation (Muga \& Mihelcic, 2008). Furthermore, the design process must be started with an accurate determination of water consumption and wastewater generation. Both factors are influenced by the economic condition, the number of household members, educational level, and 
spatial density. The Hardjosuprapto's models are commonly used to determine the pipe dimension in Indonesia.

Due to the lack of information, this research aims to evaluate the effectiveness of pipe dimensioning process and determine whether a wastewater collector is ideal to be served as a reactor through a tracer test. The target of the research is to provide some inputs about reliable design criteria for communal system in Indonesia.

\section{METHODS}

The first step of this research is identifying the wastewater piping channel path through the built drawings and field checking with 60CSx GARMIN GPS map and Google earth. The outputs of this stage are elevations, the number of household connections and the number of inspection chamber of the existing system. The next step is identifying the Real Demand Water Survey (RDS) through questionnaire which is distributed using survey to get the representation of water demand. Furthermore, through the survey, the information regarding the economic and social condition were obtained.

Then the steps are followed by evaluating the pipe route and then selecting a segment for flow rate test by measuring the velocity and the water depth on the pipe. It is calculated by measuring the travel time of a ping pong ball that is flowing from the starting point to the end point of the segment. The velocity measurements should be made at the peak time.

The entire mathematical model used in this research is referring to (Hardjosuprapto, 2000). The determination of the average discharge at the percil pipe uses the equation as follow s:

$$
\mathrm{Q}_{\mathrm{r}}=\mathrm{pq}_{\mathrm{r}}
$$

where :

$\mathrm{Q}_{\mathrm{r}} \quad=$ wastewater average flow rate $(\mathrm{L} / \mathrm{s})$;

$\mathrm{p} \quad=$ total population (person);

$\mathrm{q}_{\mathrm{r}} \quad=$ wastewater flow rate unit $(\mathrm{L} / \mathrm{s} / 1000)$.

Meanwhile, the peak flow rate at percil pipe is calculated using the following equation (Hardjosuprapto, 2000):

$$
\mathrm{Q}_{\mathrm{pp}}=5 \mathrm{p}^{1 / 2} \mathrm{q}_{\mathrm{md}}
$$

where:

$\mathrm{Q}_{\mathrm{pp}}=$ peak wastewater design flow rate on percil pipe $(\mathrm{L} / \mathrm{s})$;

$\mathrm{p}=$ population (person in thousand); 
qmd = maximum wastewater unit $(\mathrm{L} / \mathrm{s} / 1000)$, which is calculated using the following equation (Hardjosuprapto, 2000):

$$
\mathrm{q}_{\mathrm{md}} \quad=\mathrm{f}_{\mathrm{md}} \mathrm{q}_{\mathrm{r}}
$$

Meanwhile, the peak flow rate at the end of the service pipe of \pm 50 household connections, Qps, is calculated using the following equation (Hardjosuprapto, 2000):

$$
\text { Qps }=0,7 \text { n Qppr }
$$

where:

Qps = flow rate at the end of service pipe $(\mathrm{L} / \mathrm{s})$;

$\mathrm{n} \quad=$ numbers of household connections

Qppr = average peak flow rate in percil pipe $(\mathrm{L} / \mathrm{s})$.

Two tools of dimension evaluations were used namely monogram manning and hydraulic element graph. The tracer tests were conducted to assess the Hydraulic Performance of the communal sewerage system as the reactor in actual scale (Tchobanoglous, et al., 2003). The tracer used is $\mathrm{NaCl}$. The tracer concentration is measured by using a conductivity meter which gives the conductivity value in $\mu \mathrm{S} / \mathrm{cm}$ unit. The unit is needed to make a tracer response curve as a unit of concentration $(\mu \mathrm{g} / \mathrm{L}$ or $\mathrm{mg} / \mathrm{L})$. The unit conversion is conducted using the calibration curve bellow. The tracer test was at the same segment as the flow measurement. During the tracer test, some glass equipments were used to take the sample and the condictivity measurement was conducted on site.

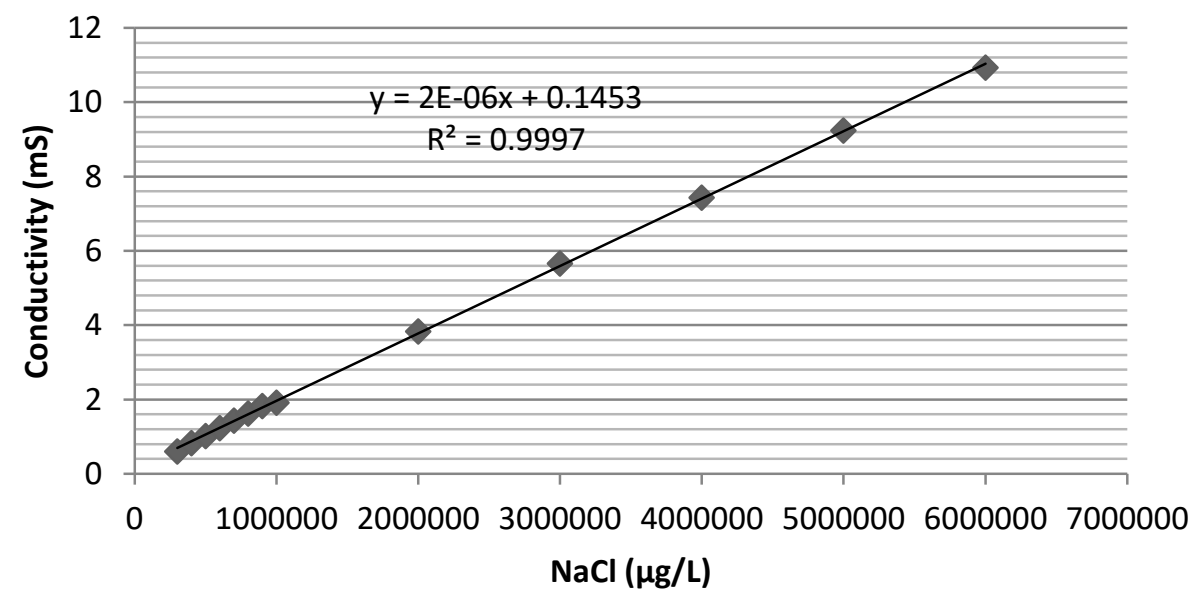

Figure 1. The calibration curve between Conductivity and $\mathrm{NaCl}$ Concentration

The mean residence time of the plug flow reactor is determined by equation 5 as follows (Tchobanoglous, et al., 2003), where $t$ is time and c is concentration.

$$
M R T=\mathrm{t}_{\Delta \mathrm{c}}=\frac{\sum t_{i} C_{i} \Delta t_{i}}{\sum C_{i} \Delta t_{i}}
$$

The dispersion at the pipe can be determined using equation 6 below (Tchobanoglous, et al., 2003): 


$$
\mathrm{D}=1,01 \vee \mathrm{N}_{\mathrm{R}}^{0,875}
$$

Where:

$$
\begin{aligned}
\mathrm{V} & =\text { viscosity }\left(\mathrm{m}^{2} / \mathrm{s}\right) \\
\mathrm{Nr} & =\text { Reynold number }
\end{aligned}
$$

\section{RESULT AND DISCUSSION}

The communal sewerage system in the village of Tegal Kawung RT 05 RW 08 serves 37 households. Figure 2 shows that the system is equipped with 25 inspection chambers that are placed on every turn, or change the direction of flow, and slope changing. The longest distance between inspection chambers is $48 \mathrm{~m}$ and the shortest is $2 \mathrm{~m}$.

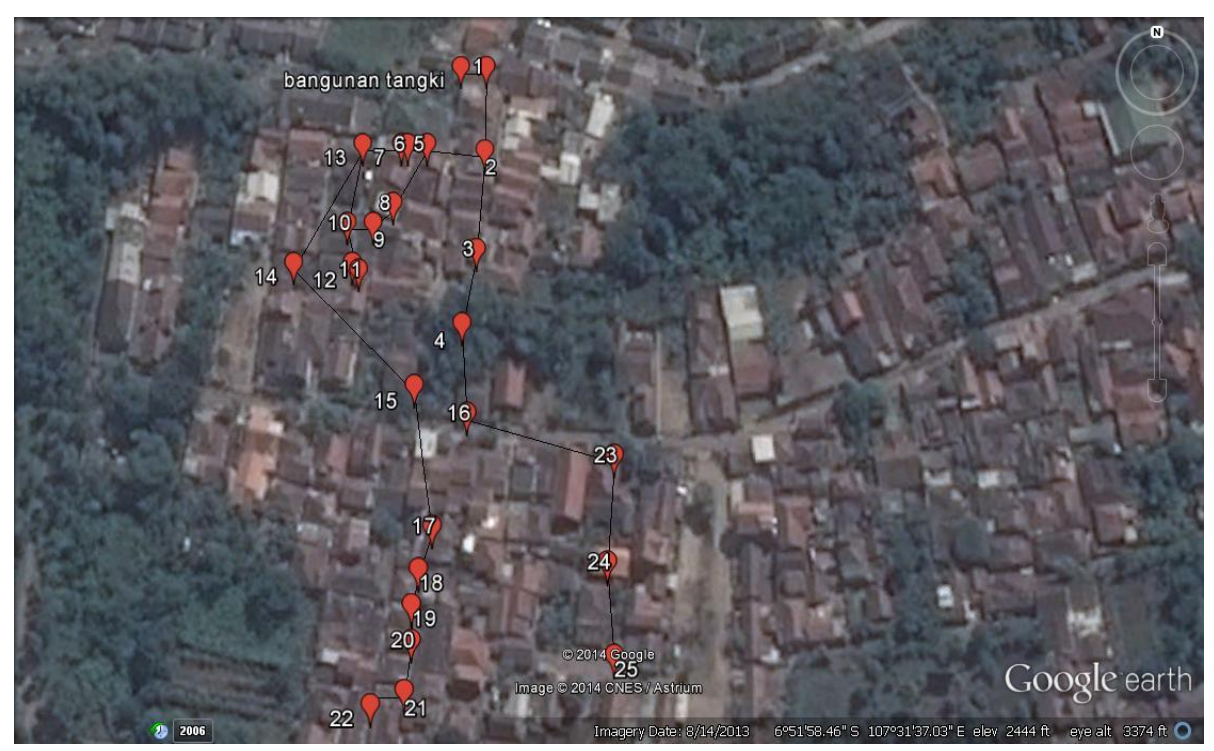

Figure2. Communal Sewerage System

The measurement point determination is based on the conditions in which no influent of new wastewater on the segment and whether its chamber can be opened easily or not to allow the measurement of water level and the velocity of wastewater in the pipeline. The starting point in this research is on the control tank number 2 of the communal system, while the end point is at the inlet channel to the septic tank. The distance of the starting point to the end point is $27.94 \mathrm{~m}$. The diameter of the pipe is $150 \mathrm{~mm}$. The condition of those points is shown in Figure 3. 


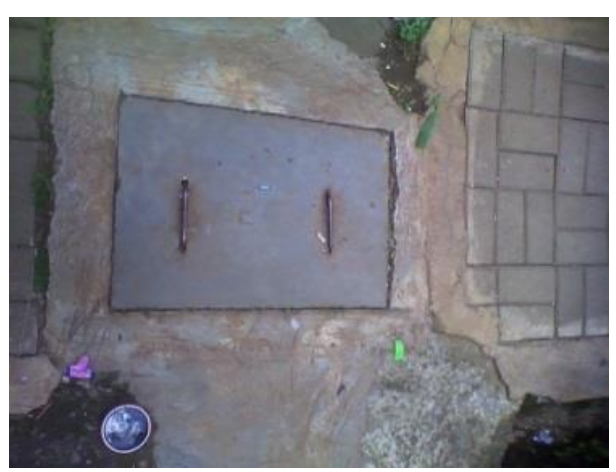

(a)

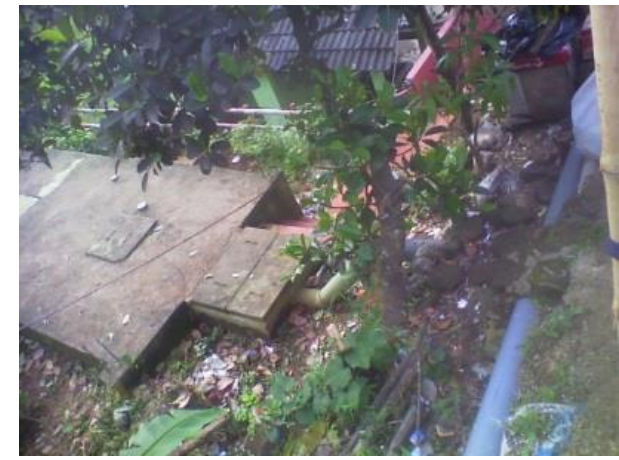

(b)

Figure 3. The condition of: (a) Inspection chamber no.2; (b) inlet of the septic tank

Most of the communities at RW 08 Cipageran Village work as construction laborers, merchants and factory workers, whereas the rest works as civil and private servants. The source of water used by the communities to fullfill their daily needs comes from the individual system from springs and wells. Figure 4 shows the income of the users of the system. The numbers of family members are around 4 people per house. The survey showed that $46 \%$ of their income is around of Rp. 500,001-1,000,000, and more than $25 \%$ of the population earns less than Rp. 500,000. This should be made as a consideration.

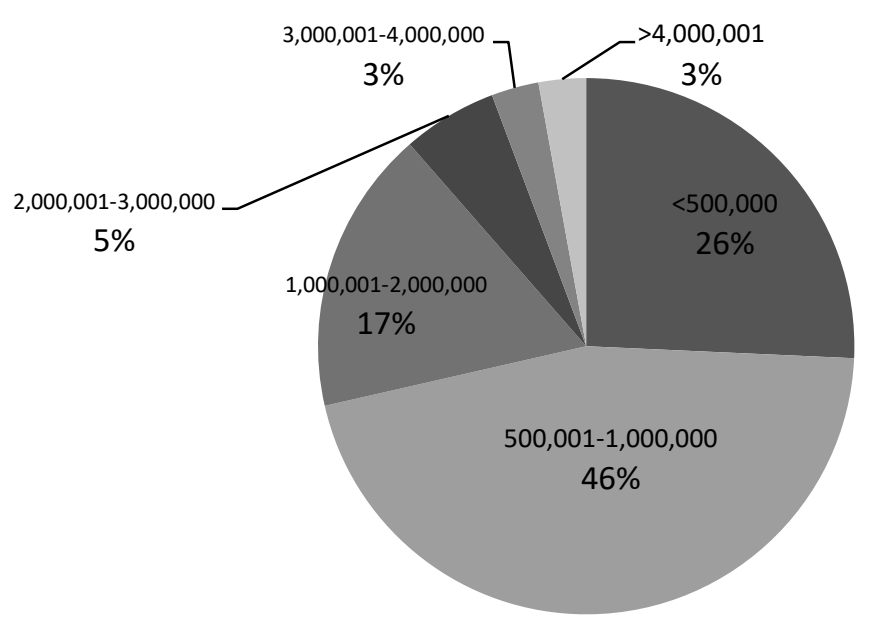

Figure 4. The income (in Indonesian Rupiah) of Household served by the system

The number of communal septic tank user is 150 people who have the amount of water consumption by 20,150 liters per day, or approximately $134.33 \mathrm{~L} /$ person/day. The values obtained from numbers of buckets used a day, when compared to the standard of water needs from Ministry of Public Work Decree No. 18/ 2007 makes Cimahi to be classified as a medium city with water demand of 150 L/person/day. The number of people who work as construction workers with the income mostly less than Rp. 1,000,000 affect the water consumption patterns. 
Other important information is about the return factor of water consumption to wastewater quantity. We found that more than $75 \%$ of the user discharge both grey and black water to the system. Due to that fact, the percentage of return factor is $80 \%$ so that the domestic wastewater quantity on this area is about $107.46 \mathrm{~L} /$ persons/day.

Comparison between the measured speed and the modeling results are shown at Figure 5. We conduct 6 time velocity measurement on working and weekend days at peak hours. Figure 5 shows that there is no significant difference on working and weekend days. Based on the mathematical model presented in the methodology, the quantity of wastewater at the segment (between control tank number 2 - inlets of communal septic tank), and the velocity at peak is $2.5 \mathrm{~m} / \mathrm{s}$. This model assumes that the flow of wastewater is steady and uniform, which means that there is no change of velocity with respect to time.

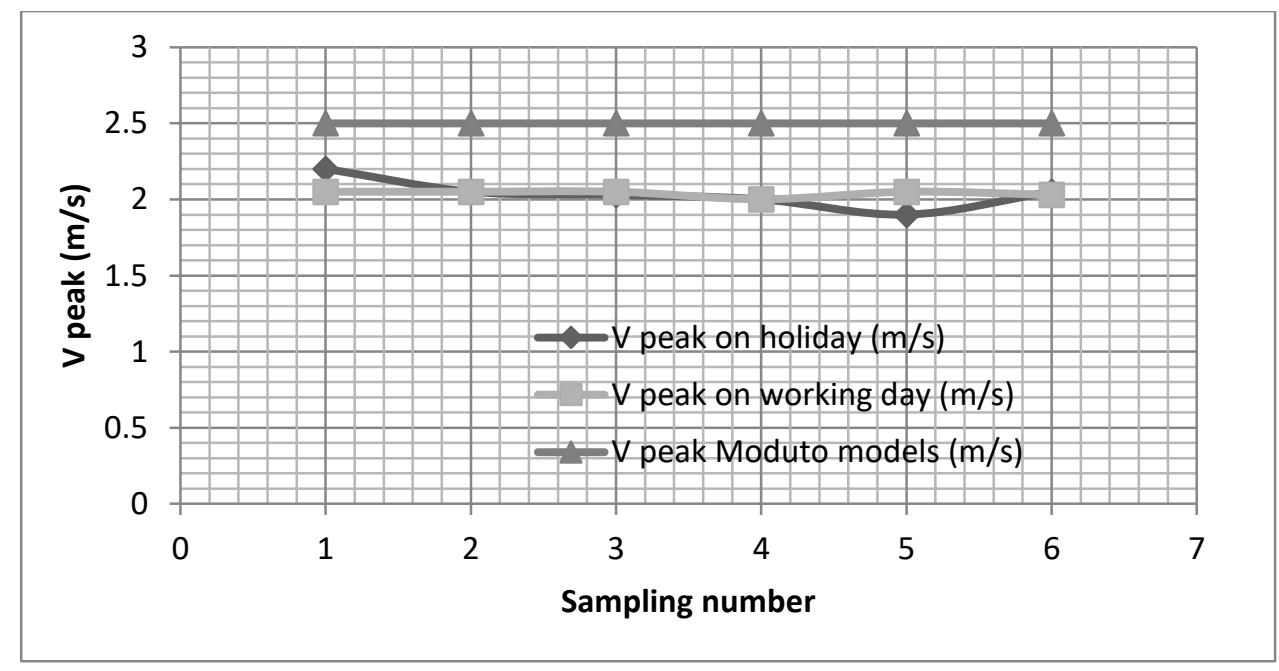

Figure 5. Velocity Comparison (V peak)

According to the model, the dimension of the pipe is determined by both hydraulic element graph and monograms manning. The diameter of the pipe should be $100 \mathrm{~mm}$. The actual diameter $(150 \mathrm{~mm})$ used in the system is still too large. This opinion is strengthen through our finding during the velocity measurement, the height of the wastewater at the pipe is only $0.6-1.7 \mathrm{~cm}$, in the meantime the minimum height of the wastewater at the pipe is $5 \mathrm{~cm}$ (Hardjosuprapto, 2000). As the consequence of that condition, the solid (feces) is aground and will decompose at the pipe not at the septic tank. Another effect of this circumstance is the bad odor due to the formation of gases from the decomposition process.

The concentration of $\mathrm{NaCl}$ in the tracer test is shown at Figure 6. The mean residence time is calculated by equation 5 and it is found that the residence time at this segment is only 0.54 minute, while the dispersion is $0.01 \mathrm{~m}^{2} / \mathrm{s}$. Finally, in order to identify the type of channel of the communal 
wastewater as a Plug Flow Reactor, MDI (Morill Dispersion Index) is calculated (Tchobanoglous, et al., 2003).

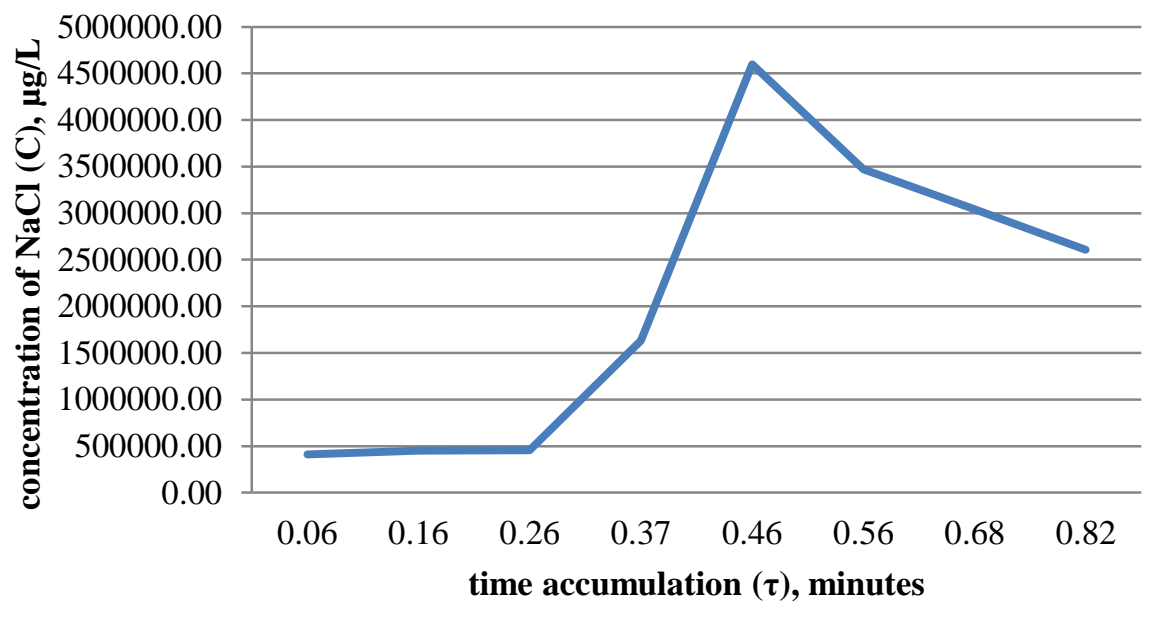

Figure 6. Time accumulation and concentration of $\mathrm{NaCl}$

Figure 7 below represents the cummulative concentration and the percentage which have been calculated. The MDI is calculated by $\frac{P_{90}}{P_{10}}$, the MDI has a value of 3.36, and showed the piping system is the Plug Flow Reactor but it is still not yet effective.

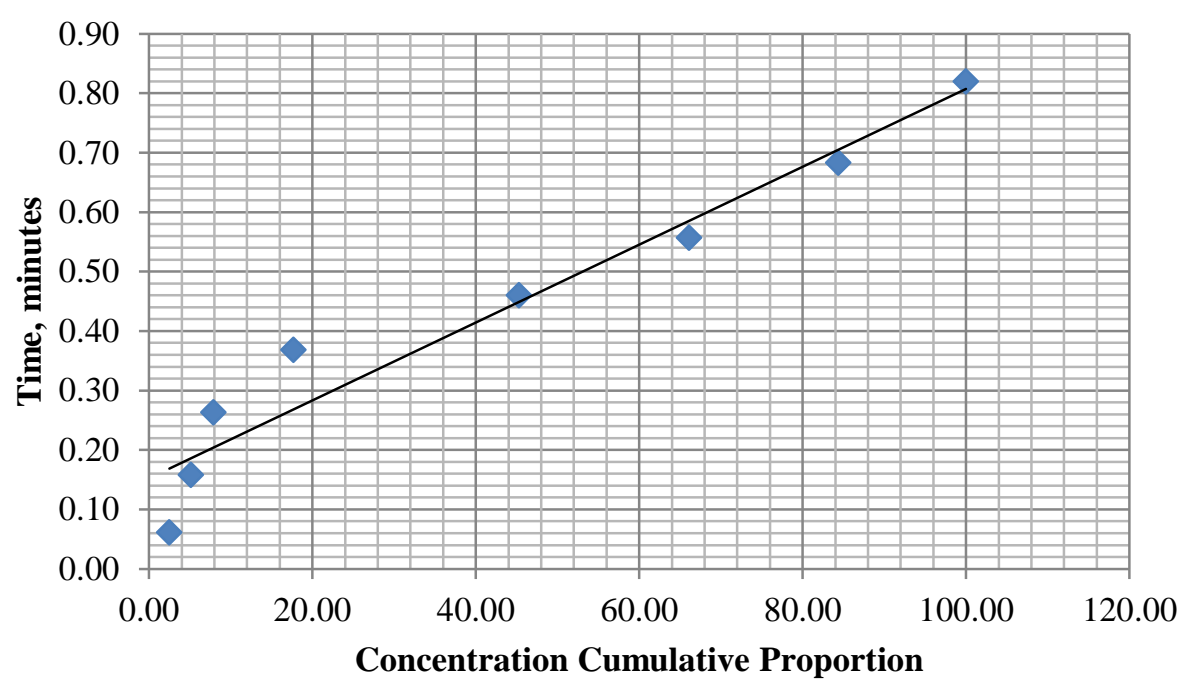

Figure 7. Concentration cummulative Proportion and Time

\section{CONCLUSIONS}

Before calculating the dimension of the pipe, the quantity of the wastewater generation must be determined. Those steps will have some important advantages: the more optimum pipe dimension; 
preventing unnecessary additional investment cost; and a better system performance to transport the wastewater to the septic tank.

The pipe of the wastewater is non-ideal PFR, a further investigation to make it more ideal is necessary.

\section{ACKNOWLEDGEMENT}

We would like to say thank you for Dinas Kebersihan dan Pertamanan of Cimahi City for their contribution to give us permit to do the research.

\section{REFERENCES}

Badan perencanaan dan pembangunan Kota Cimahi. (2013). Rencana Tata Ruang Wilayah Kota Cimahi 2012-2031. Cimahi: Pemerintah Kota Cimahi.

Cumming, O. (2009). The Sanitation imperative: A strategic response to a development crisis. Journal Desalination, 24; 8-13.

Hardjosuprapto, M. M. (2000). Penyaluran Air Buangan Vol II. Bandung: InstitutTeknologi Bandung.

Huisman, J. (2001). Transport and transformation processes in combined sewers ETH Zürich, No. 13989. Technische Wissenschaften, Eidgenössische Technische Hochschule.

Hvitved-Jacobsen, T., Vollertsen, J., \& Nielsen, A. H. (2001). Sewer Processes: Microbial and Chemical Process Engineering of Sewer Networks. CRC Press.

Kantor Lingkungan Hidup Kota Cimahi. (2010). Status Lingkungan Hidup Daerah Kota Cimahi . Cimahi: Pemerintah Kota Cimahi.

Katukiza, A., Ronteltap, M., Niwagaba, C., Foppen, J., Kansiime, F., \& Lens, P. (2012). Sustainable Sanitation Technology Option For Urban Slum. Journal Of Biotechnology Advances, 30, $964-$ 978.

Mara, D. (2003). Water sanitation and hygiene for the health of developing nations. Journal Of The Royal Institue Of Public Health, 117, 452-456. . 
Muga, H. E., \& Mihelcic, J. R. (2008). Sustainability Of Wastewater Treatment Technologies. Journal of Environmental Management, 88, 437-447.

Murphy, M., Heather, M., Edward, A., \& Farahbaskh, K. (2009). Appropriate technology-A comprehensive approach for water and sanitation in developing word . Journal Technology in Society, 31, 158-167.

Tchobanoglous, G. L., Burton, F., \& Stensel, H. D. (2003). Wastewater Engineering Treatment and Reuse, 4th Edition. New York.: McGraw - Hill Book Co. 